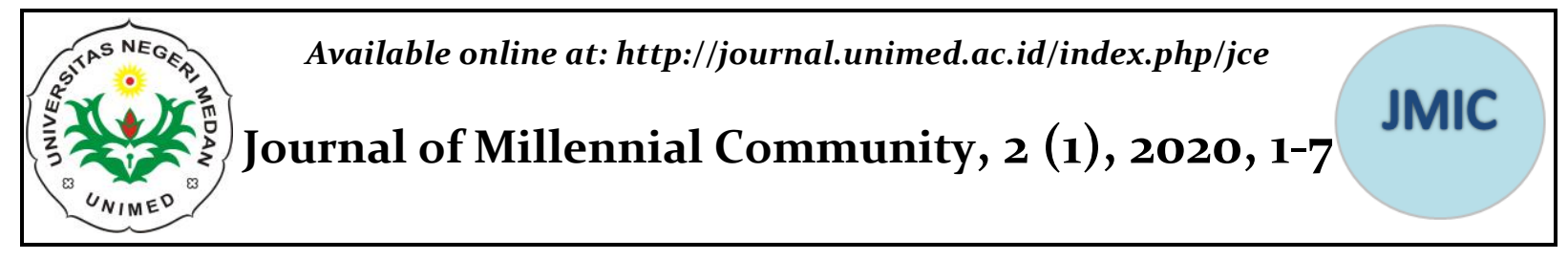

\title{
Sikap Pemulung Dalam Memelihara Kesehatan Lingkungan Di Kelurahan Tegal Sari Mandala II Kecamatan Medan Denai
}

\author{
Putri Anggreani Marbun', Dinda Nauli Lubis ${ }^{2}$ \\ ${ }^{1}$ TK RK Bintang Timur, Pematang Raya, Pematang Siantar \\ ${ }^{2}$ Program Studi Pendidikan Masyarakat, Universitas Negeri Medan \\ Email : putria.marbun@yahoo.co.id
}

\begin{abstract}
Abstrak
Penelitian ini bertujuan untuk mengetahui Sikap Pemulung Dalam Memelihara Kesehatan Lingkungan di Kelurahan Tegal Sari Mandala II Kecamatan Medan Denai. Jenis penelitian menggunakan penelitian deskriptif kuantitatif. Sampel penelitian 50 pemulung. Teknik pengumpulan data penelitian menggunakan angket. Teknik analisis data menggunakan rumus persentase $\mathrm{P} \quad \mathrm{x} 100 \%$. Hasil penelitian menunjukkan sikap kognitif pemulung dalam memelihara kesehatan lingkungan lebih memilih jawaban Kurang Baik (25,03\%). Sikap afektif pemulung dalam memelihara kesehatan lingkungan lebih memilih jawaban Sangat Baik (76\%). Sikap konatif pemulung dalam memelihara kesehatan lingkungan lebih memilih jawaban Sangat Baik (76\%). Pemulung belum sepenuhnya bersikap kognitif dalam memelihara kesehatan lingkungannya, sikap afektif pemulung ikut merasakan senang dalam memelihara kesehatan lingkungan, dan sikap konatif pemulung telah adanya tindakan/upaya nyata pemulung dalam memelihara kesehatan lingkungannya. Dengan demikian sikap pemulung dalam memelihara kesehatan lingkungan di Kelurahan Tegal Sari Mandala II Kecamatan Medan Denai sudah dapat dikatakan sangat baik.
\end{abstract}

Kata Kunci: Sikap, Pemulung, Kesehatan Lingkungan

\begin{abstract}
This study aims to determine the attitude of Scavengers in Maintaining Environmental Health in the Village of Tegal Sari Mandala II, Medan Denai District. This type of research uses quantitative descriptive research. The research sample is 50 scavengers. Research data collection techniques using a questionnaire. The data analysis technique uses the percentage formula $P x$ $100 \%$. The results showed the cognitive attitude of scavengers in maintaining environmental health prefer Less Good answers (25.03\%). Affective attitude of scavengers in maintaining environmental health prefers the Very Good answer (76\%). Conative attitude of scavengers in maintaining environmental health prefers the Very Good answer (76\%). Scavengers have not been fully cognitive in maintaining environmental health, scavenging affective attitudes feel happy in maintaining environmental health, and the scavenger's conative attitude has taken action / actual efforts in scavengers in maintaining environmental health. Thus the attitude of scavengers in maintaining environmental health in the Village of Tegal Sari Mandala II, Medan Denai District can already be said to be very good.
\end{abstract}

Keywords: Attitude, Scavengers, Environmental 


\section{Journal of Millennial Community, 2 (1), March 2020}

Putri Anggreani Marbun, Dinda Nauli Lubis

\section{PENDAHULUAN}

Pemulung adalah orang-orang yang bekerja dengan mengumpulkan barangbarang bekas sebagai mata pencahariannya, yang umumnya memulung diberbagai lokasi. Tidak jarang pemulung mengumpulkan sampah organik dan nonorganik dari setiap rumah tangga. Kota Medan memiliki luas 265,1 km² terdiri dari 21 kecamatan dan 151 kelurahan, salah satunya Lingkungan Binaan di Kelurahan Tegal Sari Mandala II Kecamatan Medan Denai, pemulung lebih cenderung memiliki sikap yang kurang perhatian dan peduli terhadap diri sendiri maupun lingkungan. Terkadang pemulung menggunakan waktu senggangnya hanya untuk mencari uang dikarenakan untuk memenuhi kebutuhan hidup sehari-hari. Tak jarang anak-anak ikut serta memulung sepulang sekolah dalam membantu pekerjaan orangtuanya. Pendapatan pemulung pun terkadang tidak menentu dikarenakan dalam sekali seminggu ada beberapa pemulung yang langsung menjual hasil yang di perolehnya, tetapi ada juga yang menunggu sampai banyak hasil yang diperolehnya lalu akhirnya dijual. Begitu juga dengan sikap pemulung yang perhatian dan peduli terhadap lingkungannya. Ini terlihat dari masih banyak sampah-sampah yang menumpuk diteras rumah dan berserakan dimana-mana. Parit juga ditutup sehingga jika hujan menjadi banjir. Susunan didalam rumah pun tidak teratur dan kurang tertata kerapian. Dengan demikian untuk bisa hidup lebih baik, terkadang pemulung lebih memilih untuk bersikap tidak bergantung kepada orang lain.

Di Kelurahan Tegal Sari Mandala II Kecamatan Medan Denai masih belum terpenuhinya syarat-syarat lingkungan bersih dan sehat. Dikarenakan masih ada beberapa yang masih menggunakan air minum dari air hujan maupun dari air permukaan tanah seperti parit besar. Selain itu, penggunaan air dari sumur bor dan PDAM sangat mahal karena rata-rata masyarakat tidak mampu. Sistem pengadaan air dirumah pun masih dinilai kurang, sehingga belum memenuhi syarat-syarat air sehat.
Demikian juga dengan masalah pengelolaan sampah yang masih sembarangan dan tidak membuang sampah pada tempatnya seperti plastik dan botol bekas masih banyak yang berserakan didepan rumah dan dimana-mana, dan jika terjadi hujan menjadi banjir karena parit ditutup sehingga mengakibatkan lingkungan menjadi tidak sehat.

Masalah kesehatan dapat dilihat dari kualitas fisik rumah/ permukiman yang masih rendah dan belum termasuk kriteria rumah sehat yang terbuat dari papan, susunan rumah tidak teratur, kotor, dan kurang tertata kerapian. Fasilitas untuk mandi belum dikatakan baik dikarenakan pintu kamar mandi ada yang sudah rusak. Sistem pembuangan air bekas dan kekuatan bangunan rumah pun lebih dominan sudah tua sehingga apabila ada kemungkinan sewaktu-waktu rubuh, maka rumah belum dikatakan sehat.

Sikap pemulung terhadap masalah pengelolaan sampah yang tidak efisien inilah yang menimbulkan permasalahan. Lalu semakin sulitnya mendapatkan lahan sebagai tempat pembuangan akhir sampah, sehingga kurangnya sikap pemulung untuk membuang sampah pada tempatnya. Dapat disimpulkan pemulung masih kurang peduli dalam memelihara kebersihan lingkungannya. Data dari kepala lingkungan ada sekitar 625 jiwa penduduk, tetapi yang bermayoritas sebagai pemulung terdapat di Lingkungan Binaan sebanyak 252 jiwa.

\section{METODE}

Penelitian ini dilakukan pada pemulung-pemulung di Kelurahan Tegal Sari Mandala II Kecamatan Medan Denai. Populasi dalam penelitian ini adalah seluruh pemulung di Lingkungan Binaan Kelurahan Tegal Sari Mandala II sebanyak 252 orang (Data Kantor Kepala Lingkungan). Jika populasi $\leq 100$ maka populasi dapat dijadikan sebagai sampel, tetapi jika populasi $\geq 100$ maka diambil sekitar 10-15\%, 20-25\% atau lebih (Sugiyono, 2014)". Atas dasar pendapat Sugiyono, maka pengambilan sampel dengan 
sampling acak sederhana. Sampel penelitian diambil $20 \%$ sebanyak 50 pemulung.

Peneliti menggunakan angket untuk memperoleh data penelitian yang diperlukan. Teknik analisis data yang digunakan dalam penelitian ini deskriptif kuantitatif. Maka digunakan tabel frekuensi dengan rumus:

Keterangan:

$$
\mathrm{P}=\frac{F}{N} \times 100 \%
$$

$\mathrm{P}=$ persentasi dari jawaban responden

$\mathrm{F}=$ frekuensi jawaban

$\mathrm{N}=$ jumlah keseluruhan responden

Adapun pengukuran variabel didasarkan pada skala likert yaitu:

$\mathrm{o} \%-25 \%=$ Kurang Baik

26\%-50\% = Tidak Baik

$51 \%-75 \%=$ Baik

$76 \%-100 \%=$ Sangat Baik

\section{HASIL DAN PEMBAHASAN}

\section{Rekapitulasi Sikap Kognitif Pemulung}

Tabel 1

Rekapitulasi Sikap Kognitif Pemulung

Dalam Kualitas Fisik Rumah

\begin{tabular}{|c|c|c|c|c|}
\hline \multirow[b]{2}{*}{$\begin{array}{c}\text { No. } \\
\text { Item }\end{array}$} & \multicolumn{4}{|c|}{ Hasil Jawaban } \\
\hline & $\begin{array}{c}\text { SB } \\
\text { (Sangat } \\
\text { Baik) } \\
\end{array}$ & $\begin{array}{c}\text { B } \\
\text { (Baik) }\end{array}$ & $\begin{array}{c}\text { KB } \\
\text { (Kurang } \\
\text { Baik) } \\
\end{array}$ & $\begin{array}{c}\text { TB } \\
\text { (Tidak } \\
\text { Baik) }\end{array}$ \\
\hline 1. & 12 & 12 & 13 & 12 \\
\hline 2. & 13 & 12 & 13 & 12 \\
\hline 3. & 12 & 12 & 12 & 13 \\
\hline 4. & 12 & 13 & 12 & 12 \\
\hline Jumlah & 49 & 49 & 50 & 49 \\
\hline $\mathbf{X}$ & 12,45 & 12,45 & 12,515 & 12,45 \\
\hline $\begin{array}{l}\frac{\mathrm{F}}{\mathrm{N}} \mathrm{x} 100 \\
\%\end{array}$ & $\begin{array}{l}\frac{12,45}{50} \times 100 \% \\
=24,99 \%\end{array}$ & $\begin{array}{l}\frac{12,45}{50} \times 100 \% \\
=24,99 \\
\%\end{array}$ & $\begin{array}{l}\frac{12,515}{50} \times 100 \% \\
=25,03 \%\end{array}$ & $\begin{array}{l}\frac{12,45}{50} \times 100 \% \\
=24,99 \%\end{array}$ \\
\hline
\end{tabular}

Hasil jawaban SB, B, TB masingmasing 24,99\%, dan KB 25,03\%. Dapat disimpulkan bahwa sikap kognitif pemulung dalam kualitas fisik rumah lebih memilih jawaban “KB 25,03\%". Hal ini dikarenakan lingkungan rumah mereka belum terpenuhi syarat kualitas fisik rumah sehat dan belum dapat dikategorikan sebagai salah satu kriteria rumah sehat.
Tabel 2

Rekapitulasi Sikap Kognitif

Dalam Penyediaan Air Bersih

Hasil Jawaban

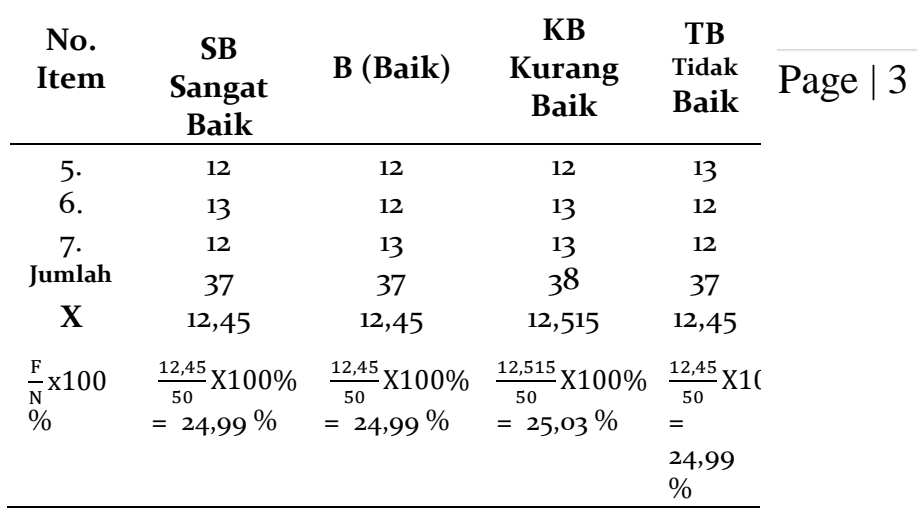

Hasil jawaban SB, B, TB masingmasing 24,99\%, dan KB 25,03\%. Dapat disimpulkan bahwa sikap kognitif pemulung dalam penyediaan air bersih lebih dominan memilih jawaban "KB 25,03\%". Hal ini dikarenakan sistem pengadaan air di rumah belum memenuhi syarat-syarat air sehat, serta air di rumah digunakan bukan hanya untuk makan dan minum tetapi untuk menyuci dan lainnya.

Tabel 3

Rekapitulasi Sikap Kognitif Dalam Pengelolaan Sampah Hasil Jawaban

\begin{tabular}{|c|c|c|c|c|}
\hline $\begin{array}{l}\text { No. } \\
\text { Item }\end{array}$ & $\begin{array}{c}\text { SB } \\
\text { Sangat } \\
\text { Baik }\end{array}$ & B (Baik) & $\begin{array}{c}\text { KB } \\
\text { Kurang } \\
\text { Baik }\end{array}$ & $\begin{array}{c}\text { TB } \\
\text { Tidak } \\
\text { Baik }\end{array}$ \\
\hline 8. & 12 & 12 & 12 & 13 \\
\hline 9. & 13 & 12 & 13 & 12 \\
\hline 10. & 12 & 13 & 13 & 12 \\
\hline Jumlah & 37 & 37 & 38 & 37 \\
\hline $\mathbf{X}$ & 12,45 & 12,45 & 12,515 & \\
\hline & & & & 12,45 \\
\hline $\begin{array}{c}\frac{\mathrm{F}}{\mathrm{N}} \times 100 \\
\%\end{array}$ & $\begin{array}{l}\frac{12,45}{50} \times 100 \% \\
=24,99 \%\end{array}$ & $\begin{array}{l}\frac{12,45}{50} \times 100 \% \\
=24,99 \%\end{array}$ & $\begin{array}{l}\frac{18,4}{50} \times 100 \% \\
=25,03 \%\end{array}$ & $\begin{array}{l}\frac{12,45}{50} \times 1 \\
= \\
24,9 \\
9 \%\end{array}$ \\
\hline
\end{tabular}

Hasil jawaban SB, B, TB masingmasing 24,99\%, dan KB 25,03\%. Dapat disimpulkan sikap kognitif pemulung dalam pengelolaan sampah lebih dominan memilih jawaban "KB 25,03\%". Hal ini dikarenakan plastik, botol-botol bekas, dan barangbarang yang tidak terpakai lagi belum 
dikelola dengan baik, serta sampah tidak dibuang ditempatnya. Padahal pemulung telah mengetahui bahwa kebersihan sebagian dari iman.

\section{Rekapitulasi Sikap Afektif Pemulung}

Tabel 4

Rekapitulasi Sikap Afektif Pemulung Dalam Kualitas Fisik Rumah

\begin{tabular}{|c|c|c|c|c|}
\hline \multirow[b]{2}{*}{$\begin{array}{l}\text { No. } \\
\text { Item }\end{array}$} & \multicolumn{4}{|c|}{ Hasil Jawaban } \\
\hline & $\begin{array}{c}\text { SB } \\
\text { Sangat } \\
\text { Baik } \\
\end{array}$ & B (Baik) & $\begin{array}{c}\text { KB } \\
\text { Kurang } \\
\text { Baik } \\
\end{array}$ & $\begin{array}{c}\text { TS } \\
\text { Tidak } \\
\text { Baik }\end{array}$ \\
\hline 11. & 38 & 10 & 2 & - \\
\hline 12. & 38 & 10 & 2 & - \\
\hline 13. & 38 & 10 & 2 & - \\
\hline 14. & 38 & 10 & 2 & - \\
\hline $\begin{array}{c}\text { Jumla } \\
\mathbf{h}\end{array}$ & 152 & 40 & 8 & - \\
\hline $\mathbf{X}$ & 38 & 10 & 2 & - \\
\hline $\begin{array}{l}P \frac{F}{N} \times 10 \\
\%\end{array}$ & $\begin{array}{l}\frac{38}{50} \times 100 \% \\
=76 \%\end{array}$ & $\begin{array}{l}\frac{10}{50} \times 100 \% \\
=20 \%\end{array}$ & $\begin{array}{l}\frac{2}{50} \times 100 \% \\
=4 \%\end{array}$ & - \\
\hline
\end{tabular}

Hasil jawaban $\mathrm{SB}=76 \%, \mathrm{~B}=\mathbf{2 0} \%, \mathrm{~KB}=4 \%$ dan $\mathrm{TB}=\mathrm{O} \%$. Dapat disimpulkan bahwa sikap afektif pemulung dalam kualitas fisik rumah/ permukiman lebih dominan memilih jawaban "SB 76\%". Hal ini dikarenakan pemulung merasa senang telah terpenuhinya fasilitas mandi di rumah, serta merasa senang juga rumah maupun lingkungan telah tertata kerapian dan kebersihan (menimbulkan respon positif). Begitu pula sebaliknya. Pemulung tidak merasa senang apabila tidak terpenuhinya fasilitas mandi di rumah, serta merasa tidak senang juga apabila rumah maupun lingkungan tidak tertata kerapian dan kebersihan.

\section{Tabel 5}

Rekapitulasi Sikap Afektif Dalam Penyediaan Air Bersih

\begin{tabular}{ccccc}
\hline No. & \multicolumn{5}{c}{ Hasil Jawaban } \\
Item & $\begin{array}{c}\text { SB } \\
\text { Sangat } \\
\text { Baik }\end{array}$ & $\begin{array}{c}\text { Baik } \\
\text { (Baik) }\end{array}$ & $\begin{array}{c}\text { KB } \\
\text { Kurang } \\
\text { Baik }\end{array}$ & $\begin{array}{c}\text { TB } \\
\text { Tidak } \\
\text { Baik }\end{array}$ \\
\hline 15. & 38 & 12 & - & - \\
16. & 38 & 12 & - & - \\
17. & 38 & 12 & - & - \\
Jumlah & 114 & 36 & - & - \\
& & & - & - \\
$\mathrm{X}$ & 38 & 12 & - & - \\
$\mathrm{P} \frac{F}{N} \times 10 \mathrm{C}$ & $\frac{38}{50} \times 100 \%$ & $\frac{12}{50} \times 100 \%$ & - & \\
$\%$ & $=76 \%$ & $=24 \%$ & & \\
\hline
\end{tabular}

Hasil jawaban $\mathrm{SB}=76 \%, \mathrm{~B}=24 \%$, KB dan TB masing-masing o\%. Dapat disimpulkan bahwa sikap afektif pemulung dalam penyediaan air bersih lebih memilih jawaban "SB 76\%". Hal ini dikarenakan pemulung merasa senang terhadap air yang digunakan untuk minum, makan, menyuci, dan lainlain telah memenuhi kriteria penyediaan air bersih (respon positif). Begitu pula sebaliknya. Pemulung merasa tidak senang terhadap air yang digunakan untuk minum, makan, menyuci, dan lain-lain tidak memenuhi kriteria penyediaan air bersih (respon negatif).

Tabel 6

Rekapitulasi Sikap Afektif Dalam Pengelolaan Sampah

\begin{tabular}{|c|c|c|c|c|}
\hline \multirow[b]{2}{*}{$\begin{array}{c}\text { No } \\
\text { Item }\end{array}$} & \multicolumn{4}{|c|}{ Hasil Jawaban } \\
\hline & $\begin{array}{c}\text { SB } \\
\text { (Sangat } \\
\text { Baik) }\end{array}$ & $\begin{array}{c}\text { Baik } \\
\text { (Baik) }\end{array}$ & $\begin{array}{c}\text { KB } \\
\text { (Kurang } \\
\text { Baik) }\end{array}$ & $\begin{array}{c}\text { TB } \\
\text { (Tidak } \\
\text { Baik) }\end{array}$ \\
\hline 18. & 13 & 12 & 12 & 12 \\
\hline 19. & 12 & 12 & 13 & 13 \\
\hline 20. & 12 & 13 & 13 & 12 \\
\hline Jumlah & 37 & 37 & 38 & 37 \\
\hline $\mathbf{X}$ & 12,45 & 12,45 & 12,515 & 12,45 \\
\hline $\begin{array}{l}P \frac{F}{N} \times 10 C \\
\%\end{array}$ & $\begin{array}{l}\frac{12,45}{50} \times 100 \% \\
=24,99 \%\end{array}$ & $\begin{array}{l}\frac{12,45}{50} \times 100 \% \\
=24,99 \%\end{array}$ & $\begin{array}{l}\frac{18,4}{50} \times 100 \% \\
=25,03 \%\end{array}$ & $\begin{array}{l}\frac{12,45}{50} \times 100 \% \\
=24,99 \%\end{array}$ \\
\hline
\end{tabular}

Hasil jawaban SB, B, TB masingmasing 24,99\%, dan $\mathrm{KB}=\mathbf{2 5 , 0 3 \%}$. Dapat disimpulkan bahwa sikap afektif pemulung dalam pengelolaan sampah lebih dominan memilih jawaban "KB 25,03\%". Hal ini dikarenakan pemulung belum dapat memisahkan sampah organik dan nonorganik, serta tidak membuang sampah ditempatnya. Padahal saat membuang sampah ditempatnya, pemulung tidak mau diperintah/pun dipaksa.

\begin{tabular}{ccccc} 
Rekapitulasi Sikap Konatif Pemulung \\
Tabel 7 \\
\multicolumn{5}{c}{ Rekapitulasi Sikap Konatif Pemulung } \\
Dalam Kualitas Fisik Rumah \\
\hline \multicolumn{5}{c}{ Hasil Jawaban } \\
No. & $\begin{array}{c}\text { SB } \\
\text { Item }\end{array}$ & $\begin{array}{c}\text { S (Baik) } \\
\text { Baik }\end{array}$ & $\begin{array}{c}\text { KB } \\
\text { Kurang } \\
\text { Baik }\end{array}$ & $\begin{array}{c}\text { TB } \\
\text { Tidak } \\
\text { Baik }\end{array}$ \\
\hline 21. & 13 & 12 & 12 & 12
\end{tabular}

Page $\mid 4$ 
Journal of Millennial Community, 2 (1), March 2020

Putri Anggreani Marbun, Dinda Nauli Lubis

\begin{tabular}{ccccc}
\hline 22. & 12 & 12 & 13 & 13 \\
23. & 12 & 13 & 13 & 12 \\
Jumlah & 37 & 37 & 38 & 37 \\
$\mathrm{X}$ & 12,45 & 12,45 & 12,515 & 12,45 \\
$\mathrm{P} \frac{\mathrm{F}}{\mathrm{N}} \times 10$ & $\frac{12,45}{50} \times 100 \%$ & $\frac{12,45}{50} \times 100 \%$ & $\frac{18,4}{50} \times 100 \%$ & $\frac{12,45}{50} \times 1$ \\
$\%$ & $=24,99 \%$ & $=24,99 \%$ & $=25,03 \%$ & $\begin{array}{l}= \\
=\end{array}$
\end{tabular}

Hasil jawaban SB, B, TB masingmasing 24,99\%, dan KB 25,03\%. Dapat disimpulkan bahwa sikap konatif pemulung dalam kualitas fisik rumah/permukiman lebih memilih jawaban "KB 25,03"\%. Hal ini dikarenakan fasilitas mandi di rumah pemulung tidak/pun belum terpenuhi, serta masih minoritasnya kualitas fisik rumah pemulung yang memiliki jendela dan penerangan yang cukup.

\section{Tabel 8}

Rekapitulasi Sikap Konatif Dalam Penyediaan Air Bersih

\begin{tabular}{|c|c|c|c|c|}
\hline \multirow[b]{2}{*}{$\begin{array}{c}\text { No. } \\
\text { Item }\end{array}$} & \multicolumn{4}{|c|}{ Hasil Jawaban } \\
\hline & $\begin{array}{c}\text { SB } \\
\text { (Sangat } \\
\text { Baik) }\end{array}$ & B (Baik) & $\begin{array}{c}\text { KB } \\
\text { (Kurang } \\
\text { Baik) }\end{array}$ & $\begin{array}{c}\text { TB } \\
\text { (Tidak } \\
\text { Baik) }\end{array}$ \\
\hline 24. & 13 & 12 & 12 & 12 \\
\hline 25 & 12 & 12 & 13 & 13 \\
\hline 26. & 12 & 13 & 13 & 12 \\
\hline Jumlah & 37 & 37 & 38 & 37 \\
\hline $\mathbf{X}$ & 12,45 & 12,45 & 12,515 & 12,45 \\
\hline $\begin{array}{l}\mathrm{P} \frac{\mathrm{F}}{\mathrm{N}} \times 100 \\
\%\end{array}$ & $\begin{array}{l}= \\
\frac{12,45}{50} \times 100 \% \\
=24,99 \%\end{array}$ & $\begin{array}{l}= \\
\frac{12,45}{50} \times 100 \% \\
=24,99 \%\end{array}$ & $\begin{array}{l}= \\
\frac{18,4}{50} \times 100 \% \\
=25,03 \%\end{array}$ & $\begin{array}{l}= \\
\frac{12,45}{50} \times 100 \% \\
=24,99 \%\end{array}$ \\
\hline
\end{tabular}

Hasil jawaban SB, B, TB masingmasing 24,99\%, dan KB 25,03\%. Dapat disimpulkan bahwa sikap konatif pemulung dalam penyediaan air bersih lebih dominan memilih jawaban "KB 25,03\%". Walaupun sistem pembuangan air bekas telah berupaya dipenuhi pemulung, tetapi masih minoritas pemulung mengupayakan untuk terpenuhinya sistem pengadaan air di rumah, serta belum/pun tidak diupayakan terpenuhinya syarat-syarat dari penyediaan air bersih.
Tabel 9

Rekapitulasi Sikap Konatif

Dalam Pengelolaan Sampah

\begin{tabular}{ccccc}
\hline \multicolumn{5}{c}{ Hasil Jawaban } \\
$\begin{array}{c}\text { No. } \\
\text { Item }\end{array}$ & $\begin{array}{c}\text { SB } \\
\text { (Sangat } \\
\text { Baik) }\end{array}$ & B (Baik) & $\begin{array}{c}\text { KB } \\
\text { (Kurang } \\
\text { Baik) }\end{array}$ & $\begin{array}{c}\text { TB } \\
\text { dak } \\
\text { dak } \\
\text { Bai } \\
\mathbf{k})\end{array}$ \\
27. & 36 & 14 & - & - \\
\hline 28. & 40 & 10 & - & - \\
Jumlah & 76 & 24 & - & - \\
$\mathbf{X}$ & 38 & 12 & - & - \\
$\mathrm{P}=$ & $\frac{38}{50} \times 100 \%$ & $\frac{12}{50} \times 100 \%=$ & - & - \\
$\frac{\mathrm{F}}{\mathrm{N}} \times 100 \%$ & $=76 \%$ & $24 \%$ & - & \\
\hline
\end{tabular}

Hasil jawaban SB 76\%, B 24\%, KB dan TB o\%. Dapat disimpulkan bahwa sikap konatif pemulung dalam pengelolaan sampah lebih dominan memilih jawaban "SB $76 \%$. Hal ini dikarenakan adanya tindakan/pun upaya pemulung untuk membuang sampah ditempatnya, serta adanya tindakan/pun upaya pemulung dalam memisahkan sampah organik dan nonorganik.

\section{SIMPULAN}

a. Indikator sikap kognitif dalam kualitas fisik rumah, penyediaan air bersih dan pengelolaan sampah rata-rata 12,515. Hal ini berarti pemulung belum sepenuhnya bersikap kognitif sebanyak 25,03\%. Padahal pemulung diharapkan telah dapat mengetahui syarat-syarat dari kualitas fisik rumah yang sehat, syaratsyarat penyediaan air bersih, serta dapat mengelola sampah dengan baik.

b. Indikator sikap afektif dalam kualitas fisik rumah rata-rata 38 . Ini berarti pemulung merasakan senang rumah dan lingkungannya telah tertata rapi dan bersih sehingga adanya respon positif, begitu pun sebaliknya sebanyak $76 \%$. Hampir sama dengan indikator sikap afektif dalam penyediaan air 


\section{Journal of Millennial Community, 2 (1), March 2020}

Putri Anggreani Marbun, Dinda Nauli Lubis

bersih rata-rata $38 \%$. Ini berarti pemulung merasa senang terhadap air yang digunakan untuk minum, makan, menyuci, dan lainnya telah memenuhi kriteria penyediaan air bersih sehingga adanya respon positif, begitu punsebaliknya sekitar $76 \%$. Sedangkan indikator sikap afektif dalam pengelolaan sampah rata-rata 12,515. Hal ini berarti pemulung belum dapat memisahkan sampah organik dan nonorganik, serta tidak membuang sampah ditempatnya sekitar 25,03\%.

c. Indikator sikap konatif dalam kualitas fisik rumah dan penyediaan air bersih hampir sama rata-rata 12,515. Hal ini berarti belum adanya tindakan maupun upaya nyata pemulung agar dapat memenuhi syarat-syarat kualitas fisik rumah dan mengupayakan penyediaan air bersih yakni sebesar 25,03\%. Sedangkan sikap konatif dalam pengelolaan sampah rata-rata 36 . Hal ini berarti telah adanya tindakan maupun upaya nyata pemulung untuk membuang sampah ditempatnya, serta adanya tindakan dalam memisahkan sampah organik dan nonorganik yakni sebesar $76 \%$.

\section{DAFTAR PUSTAKA}

Ahmadi, Abu. 2007. Psikologi Sosial. Jakarta: Rhineka Cipta.

Aiken, Lewis. 2010. Psychological Testing and Assesment. Boston: Hekyians Bacon.

Arikunto, Suharsimi. 2006. Prosedur Penelitian Suatu Pendekatan Praktik Edisi Revisi VI. Jakarta: Rhineka Cipta.

Azwar, Azrul. 2009. Pengantar Ilmu Kesehatan Lingkungan. Jakarta: Mutiara Sumber Widya.
Azwar, Syaifuddin. 2009. Sikap Manusia, Teori dan Pengukurannya. Yogyakarta: Pustaka Pelajar.

Departemen Kesehatan Republik Indonesia. 1992. Undang-Undang Kesehatan No.23 Tahun 1992. Tentang Page | 6 Kesehatan. Jakarta.

Departemen Kesehatan Republik Indonesia. 2009. Undang-Undang Kesehatan No.35 Tahun 2009. Tentang Kesehatan. Jakarta.

Mar'at. 2010. Sikap Manusia, Perubahan Serta Pengukurannya Edisi Ke-2. Bandung: Graha Indonesia.

Ndraha. 2010. Budaya Organisasi. Jakarta: Bhineka Cipta.

Nainggolan, E. E., Nainggolan, E., Susanti, S., Silitonga, M. D., \& Irwan, M. (2019, December). Community Participation within the Implementation of the Senior High School Equality Education Program in PKBM Cahaya. In 5th International Conference on Education and Technology (ICET 2019). Atlantis Press.

Notoadmodjo, Seakidjo. 2009. Ilmu Kesehatan Masyarakat. Jakarta: Rhineka Cipta.

Robbbins dan Judge. 2007. Perilaku Organisasi, Buku 1 dan 2. Jakarta: Salemba Empat.

Siregar, M., \& Nasriah, N. (2019). Hubungan Tingkat Pendidikan Pasangan Usia Subur (15-49 Tahun ) Dengan Keberhasilan Program Keluarga Berencana. Journal of Millennial Community, 1(2), 51-56. doi:https://doi.org/10.24114/jmc.vii2 .14710

Slamet, Soemirat. 2009. Kesehatan Lingkungan. Yogyakarta: Gadjah Mada University Press. 
Journal of Millennial Community, 2 (1), March 2020

Putri Anggreani Marbun, Dinda Nauli Lubis

Sugiyono. 2014. Metode Penelitian Pendidikan Pendekatan Kualitatif, Kuantitatif dan RED. Bandung: Alfabeta.
Undang-Undang Nomor 4 Pasal 22 Tahun 1992 Tentang Perumahan Dan Permukiman.

Tim Dosen Unimed, 2004. Perkembangan Peserta Didik. Medan. 